\title{
Chromium reduction using organic adsorbents along with indigenous chromium resistant bacteria isolated from Lahore and Gujrat, Pakistan
}

\author{
Masooma Muzaffar ${ }^{1}$, Mawra Gohar ${ }^{1}$ and Sumaira Mazhar ${ }^{*}$ \\ 1. Department of Biology, Lahore Garrison University-Pakistan \\ *Corresponding author's email: smz.mmg@gmail.com
}

Citation

Masooma Muzaffar, Mawra Gohar and Sumaira Mazhar. Chromium reduction using organic adsorbents along with indigenous chromium resistant bacteria isolated from Lahore and Gujrat, Pakistan. Pure and Applied Biology. Vol. 10, Issue 1, pp291-301.

\begin{tabular}{|c|c|c|c|}
\hline Received: 01/06/2020 & Revised: $24 / 08 / 2020$ & Accepted: 04/09/2020 & Online First: $21 / 09 / 2020$ \\
\hline
\end{tabular}

\section{Abstract}

Heavy metals $(\mathrm{Cr}, \mathrm{Cd}, \mathrm{Cu}, \mathrm{Pb}$, etc.) are of great global health concern. As they are non-degradable, causing diseases (Skin and Lung irritability, Nausea etc.) and disorders (Lesions on Kidneys and Liver, Nervous system damage, Myocardium, Edema, etc.). So, there is a great need to recycle the waste water from industries to reuse it for different purposes. The purpose of current research was to isolate heavy metal chromium $(\mathrm{Cr})$ resistant bacteria from different industrial effluents (soil and waste water), to prepare organic adsorbents (saw dust, green tea leaves and sugarcane bagasse) that can eliminate the large amount of hexavalent chromium from different sources and considered as cheapest method for industries to remove heavy metals and to check the effect of prepared bio-sorbents on the removal of chromium metal from the wastewater separately and with the combination of chromium resistant isolates. Results showed that the maximum removal percentage of $\mathrm{Cr}(\mathrm{VI})$ was found $(89.4 \%)$ with sawdust at doses $(0.5,1$ and $1.5 \mathrm{gm})$ with optimum $\mathrm{pH}$ (2) and room temperature followed by green tea leaves $(84.6 \%)$ and sugarcane bagasse (67.8\%) with equilibrium time of 120 and 150 minutes respectively, while M1, M4 and M10 isolates showed maximum removal with the adsorbent dose of 1 gram (Saw dust, Sugarcane bagasse and Green tea leaves).

Key words: Bio sorbents; Chromium; Cheap methods; Camellia sinensis; Contamination; Effluents; Heavy-metals; Industrial effluents; Saccharum officinarum; Saw-dust

\section{Introduction}

Industries are the major sources of chromium contamination and dissemination in atmosphere indicating heavy metal pollution, which feasts over the industrial wastewater discharged into the ground [1]. Heavy metals are used frequently in industries causing increase in discharge of metal substances in water resources adjacent to industries [2, 3]. Different industrial effluents comprising mining, electroplating, tanning etc. contains a wide range of lethal heavy metals and release inform of aqueous and solid wastes [4] hazardous to natural sources of water, animal and human fitness.

Heavy metals disposal is of major concern due to their non-biodegradability and tendency to bio accumulate. Therefore, they affect human, animal's health and environmental quality [5]. Chromium $\left(\mathrm{Cr}^{+6}\right)$ a well-documented toxin and carcinogen, $[6,7]$ is one of the most potent heavy metals used in modern industries i.e. plastic, pigment, wood preservative, steel, leather tanning, cement, paint, dyeing and fertilizer [8]. Removal of toxic and 
hazardous compounds from industrial wastewater (IWW) presents a great issue for the protection of natural resources, enabling the reuse of water for the sustainable development and environmental protection [9].

Many bacteria have specific genetic mechanisms of resistance to toxic metals [10] such as, Escherichia coli, Pseudomonas aeruginosa, Klebsiella pneumoniae, Staphylococcus,

Enterococcus faecalis, Bacillus thuringiensis and Micrococcus sp. [11]. Chromium-resistant microbes are Pseudomonas aeruginosa, Bacillus sp., Pasteurella sp., Pseudomonas sp., E. coli, Staphylococcus sp. etc. [12].

Low-cost adsorbents (activated carbon) have been established rapidly from wastage materials [13]. Adsorbents have great potential to excavate heavy metals from waste water of industries due to their specific properties e.g. enormous superficial area, micro-porous nature and chemical composition of surface [14]. Adsorption is a mass removal course [15]. Now a day, Organic adsorbents surpassed the place of activated carbon [16]. Struggles towards removal of heavy metals from inorganic material, is particularly limited. In recent study three activated carbons prepared from agricultural wastes (Sugar cane bagasse, saw dust \& green tea leaves) along with locally isolated microbes were used to remove $\mathrm{Cr}$ (VI) from aqueous solution.

\section{Materials and Methods \\ Isolation and purification of chromium resistant isolates}

Surface soil $(n=9)$ and waste water samples $(n=9)$ were collected from different Industrial sites of Lahore and Gujrat (Pakistan). Wastewater samples were collected from industrial effluents in sterile screw capped containers while soil samples were collected in clean plastic bags via sterile spatula from the backyards of same Industries. All samples were transported to Biology Laboratory of Lahore Garrison University and stored at $4^{\circ} \mathrm{C}$ for further use. $1 \mathrm{~g}$ of soil sample was added in sterilized test tube containing 9 $\mathrm{mL}$ autoclaved distilled water and was vortexed for one minute. The process was repeated for all soil samples. The prepared samples were introduced onto agar using spread plate technique. 100 microliters $(\mu \mathrm{L})$ of each soil sample and water sample was taken through micropipette, plated on the LB-agar plates (prepared as per manufacturer's instructions) and spreading was done by using sterile L-shaped glass spreader. Inoculated plates were incubated for 24 hours at $37^{\circ} \mathrm{C}$. Results were observed and noted. Bacterial colonies on LB-agar plates were further purified by streak plate method. Isolates were purified to get pure cultures. The isolated colonies were taken and streaked on Luria Broth agar plates by quadrate streak method. Incubation was done for 24 hours at $37{ }^{\circ} \mathrm{C}$ and macroscopic characters were recorded and documented.

\section{Screening and identification of chromium resistant bacterial isolates}

Screening of the purified isolates was done using LB agar containing chromium (100 $\mu \mathrm{L} / \mathrm{mL}$ and $500 \mu \mathrm{L} / \mathrm{mL}$ concentrations of chromium stock solution). Purified bacterial isolates were inoculated into plates and incubated at $37{ }^{\circ} \mathrm{C}$ for 24 hours to isolate Chromium resistant bacteria. After incubation, microscopic and macroscopic characters were observed and documented. Chromium resistant bacterial isolates were identified by biochemical characterization, microscopically and macroscopically [17]. Results were observed and noted respectively.

\section{Chromium reduction with organic adsorbents}

Different adsorbents e.g. sugarcane bagasse, saw dust and green tea leaves were prepared and used. For the preparation of adsorbents, organic waste was collected from the local market of Lahore. Wastes were washed (2-3 times with distilled water) to remove the dust particles followed by drying (sun drying and hot air oven). Biomaterial was crushed 
with hands roughly and grind to a fine powder. Strained powder was saturated in Phosphoric acid $\left(\mathrm{H}_{3} \mathrm{PO}_{4}\right)(0.5: 1)$, dried at $160{ }^{\circ} \mathrm{C}$ for 15 minutes in oven for activation. The solution was then filtered using filter paper and filtrate was dried further to get the adsorbent as activated carbon. The different doses of adsorbents were then added in every flask containing $50 \mathrm{~mL}$ of wastewater having concentrations of Chromium. Results were recorded by measuring the absorbance values of chromium in each sample (at different time intervals) using spectrophotometer $(540 \mathrm{~nm})$.

\section{Chromium reduction with organic adsorbents along with chromium resistant isolates}

Similarly, adsorbent doses $(0.5 \mathrm{~g}$ and $1 \mathrm{~g})$ were added in $5 \mathrm{ml}$ cultural (M1, M2, M3....M10) test tubes having $500 \mu \mathrm{g} / \mathrm{mL}$ concentration of chromium to check the combined effect of chromium resistant bacteria and adsorbent on reduction of chromium.

\section{Results}

\section{Isolation and purification of bacteria}

Total 30 bacteria were isolated and purified from collected water and soil samples of selected industrial area (Lahore and Gujrat). 17 bacteria (57\%) were isolated from soil and 13 bacteria (43) were from water samples (Table 1). Isolated bacteria were further screened for their ability to grow in chromium containing media.

\section{Screening and identification of chromium resistant bacteria}

Out of the 30 isolated bacteria, only 10 (33.3\%) isolates showed growth and screened positive for chromium resistance as shown in (Fig. 1a \& b). Among 10 chromium resistant bacteria, $6(60 \%)$ were isolated from the water samples while from soil samples, 4 (40\%) bacteria were isolated. Resistant isolates were labelled on the basis of their source and location. Chromium resistant isolates were further identified microscopically and macroscopically. All bacterial isolates
(100\%) were gram positive purple cocci in different arrangements (chains, clusters and diplococci). Among 10 isolates, 4 $(40 \%)$ were isolated from soil samples and $6(60 \%)$ from water samples. Biochemical tests revealed the confirmation of Staphylococcus aureus and Staphylococcus epidermidis species (Table 2). Bacteria isolated from water and soil samples grown on differential and selective media (Mannitol Salt Agar, Blood Agar and Staphylococcus 110. Agar) also confirmed the presence of Staphylococcus aureus and Staphylococcus epidermidis species (Table 3).

\section{Adsorbents performance for $\mathrm{Cr}^{+6}$ removal}

Biological adsorbents were prepared to remove the chromium in order to determine the efficacy of different adsorbent (Saw dust, Sugarcane Bagasse, Green Tea Leaves). Results for the Saw Dust adsorbent indicated that maximum removal of chromium was done at time interval of 150 minutes with the dose of 1 gm $(89.4 \%)$ followed by $1.5 \mathrm{~g}(76.6 \%)$ as presented in (Fig. 2). For Sugarcane Bagasse (Saccharum officinarum), appropriate dose was $1 \mathrm{~g}(67.8 \%)$ and $1.5 \mathrm{~g}$ $(59.98 \%)$ at interval of 120 minute as shown in (Fig. 3), whereas for Green Tea Leaves (Camellia sinensis) the pattern was slightly different, maximum reduction rate was observed at dose of $1 \mathrm{~g}(84.6 \%)$ and $0.5 \mathrm{~g}(71.3 \%)$ at 120 minutes as shown in (Fig. 4). Results revealed that adsorbents provide noble consequences at low doses $(0.5 \mathrm{~g}$ to $2 \mathrm{~g})$ through appropriate time of interaction (90 to 150 minutes) with adjusted $\mathrm{pH}(2)$.

\section{Adsorbents performance in combination with microbes for $\mathrm{Cr}^{+6}$ removal}

Similarly, chromium reduction potential of chromium resistant isolates was determined by combined effect of isolates and adsorbents doses $(0.5 \mathrm{~g}$ and $1 \mathrm{~g})$ on chromium metal. Results showed that at both doses, reduction of chromium from 
chromium resistant isolates was maximum for all adsorbents used. Saw dust at dose of $0.5 \mathrm{~g}$ showed best results with isolate $\mathrm{M} 1$ (69\%), M7 (57\%), and M10 (65\%), whereas same isolates (M1, M7 and M10) showed maximum removal $(74 \%, 72 \%$ and $71 \%$ ) with dose of $1 \mathrm{~g}$. Isolates M6 (67\%), M9 (66\%) and M10 (73\%) were prominent with Camellia sinensis at dose of $0.5 \mathrm{~g}$ while M3 (78\%), M9 (82\%) and M10 (89\%) were noticeable with $1 \mathrm{~g}$ dose. Saccharum officinarum showed maximum percentage reduction with isolates M4, M8 and $\mathrm{M} 10$ at $0.5 \mathrm{~g}(62 \%, 55 \%$ and $61 \%)$ and $1 \mathrm{~g}(73 \%, 66 \%$ and $70 \%)$ as shown in (Fig. $5,6 \& 7)$.

Table 1. Number of bacterial Isolates

\begin{tabular}{|c|c|c|c|}
\hline S. No. & Sample Name & Name of Colonies & Number of Colonies \\
\hline 1 & Wood Liquid & WL & No growth \\
\hline \multirow{2}{*}{2} & \multirow{2}{*}{ Wood Soil } & WS1 & 04 \\
\hline & & WS2 & 06 \\
\hline \multirow{4}{*}{3} & \multirow{4}{*}{ Marble Liquid } & ML1 & 03 \\
\hline & & ML2 & 03 \\
\hline & & ML3 & 05 \\
\hline & & ML4 & 04 \\
\hline 4 & Marble Soil & MS1 & Numerous \\
\hline \multirow{2}{*}{5} & \multirow{2}{*}{ Steel Liquid } & SL1 & Numerous \\
\hline & & SL2 & 05 \\
\hline \multirow{2}{*}{6} & \multirow{2}{*}{ Steel Soil } & SS1 & 05 \\
\hline & & SS2 & Numerous \\
\hline \multirow{2}{*}{7} & \multirow{2}{*}{ Paint Liquid } & PL1 & 08 \\
\hline & & PL2 & 05 \\
\hline 8 & Paint Soil & PS1 & Numerous \\
\hline \multirow{2}{*}{9} & \multirow{2}{*}{ Cement Liquid } & CL1 & 06 \\
\hline & & CL2 & 06 \\
\hline 10 & Cement Soil & CS1 & 07 \\
\hline 11 & Automobile Liquid & $\mathrm{AL}$ & No growth \\
\hline \multirow{3}{*}{12} & \multirow{3}{*}{ Automobile Soil } & AS1 & 05 \\
\hline & & AS2 & Numerous \\
\hline & & AS3 & 09 \\
\hline 13 & Iron Liquid & IL & No growth \\
\hline \multirow{2}{*}{14} & \multirow{2}{*}{ Iron Soil } & IS1 & 06 \\
\hline & & IS2 & 08 \\
\hline \multirow{4}{*}{15} & & IS3 & 05 \\
\hline & & TLO1 & Numerous \\
\hline & & TL1 & 04 \\
\hline & & TL2 & 07 \\
\hline \multirow{4}{*}{16} & \multirow{4}{*}{ Textile Soil } & TSO1 & 03 \\
\hline & & TSO2 & 05 \\
\hline & & TSO3 & Numerous \\
\hline & & TS1 & Numer \\
\hline
\end{tabular}



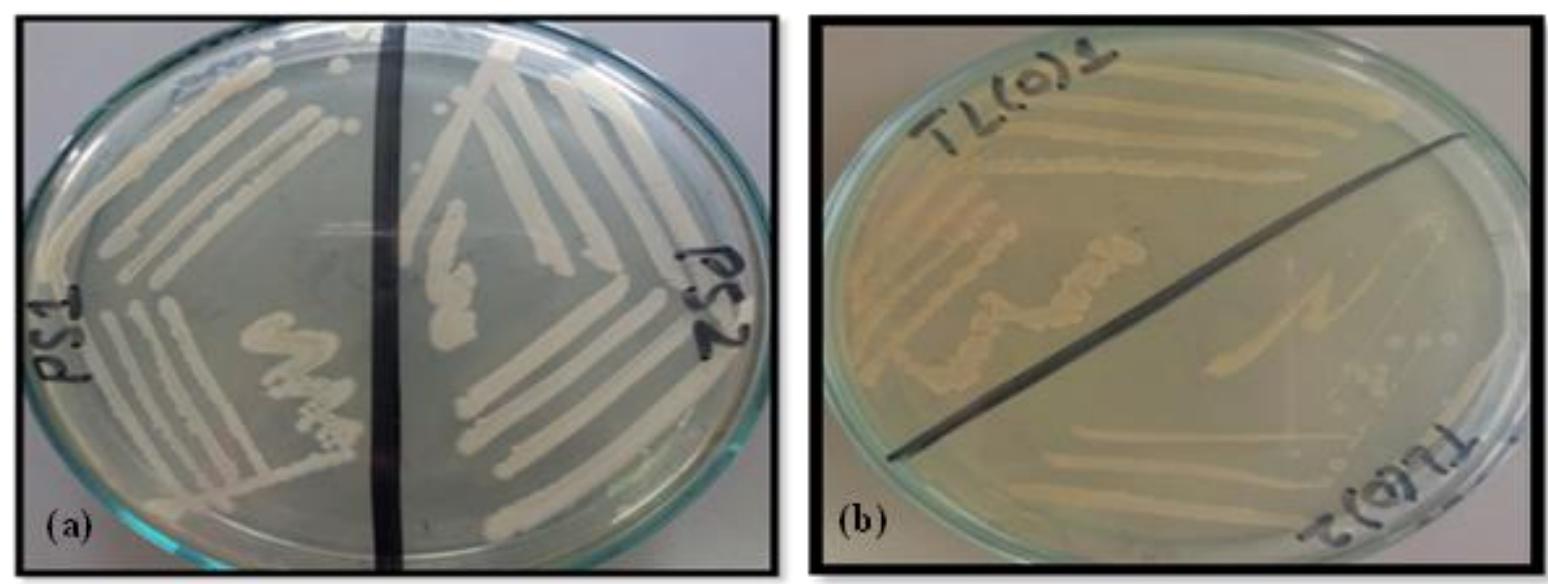

Figure 1a \& b. Screening of Chromium Resistant Bacterial Isolates of Water Samples

Table 2. Biochemical profile of bacterial isolates

\begin{tabular}{|c|c|c|c|c|c|c|c|c|}
\hline $\begin{array}{c}\text { Isolate } \\
\text { ID }\end{array}$ & MR & SIM & H2S & Catalase & Coagulase & Urease/VP & Indole & $\begin{array}{c}\text { Nitrate } \\
\text { Reduction }\end{array}$ \\
\hline IS2 & + & - & - & + & + & + & - & + \\
\hline CL2 & + & - & - & + & + & + & - & + \\
\hline TSO3 & - & - & + & + & - & + & - & + \\
\hline TL2 & + & - & - & + & + & + & - & + \\
\hline ML3 & - & - & + & + & - & + & - & + \\
\hline ML4 & + & - & - & + & + & + & - & + \\
\hline SL2 & - & - & + & + & - & + & - & + \\
\hline AS2 & + & - & - & + & + & + & - & + \\
\hline PL2 & - & - & + & + & - & + & - & + \\
\hline WS2 & - & - & + & + & - & + & - & + \\
\hline
\end{tabular}

Table 3. Growth on differential media

\begin{tabular}{|c|c|c|c|}
\hline S. No. & Mediums & $\begin{array}{c}\text { Staphylococcus } \\
\text { aureus }\end{array}$ & $\begin{array}{c}\text { Staphylococcus } \\
\text { epidermidis }\end{array}$ \\
\hline 1. & MSA medium & $\begin{array}{c}\text { +ive (Yellow) } \\
\text { (IS2, CL2, TL2, ML4 } \\
\text { and AS2) }\end{array}$ & $\begin{array}{c}\text {-ive (Pink) } \\
\text { (TSO3, ML3, SL2, } \\
\text { PL2 and WS2) }\end{array}$ \\
\hline 2. & Blood Agar & $\begin{array}{c}\beta \text {-Hemolysis (clear } \\
\text { zone) }\end{array}$ & No Hemolysis \\
\hline 3. & $\begin{array}{c}\text { Staphylococcus 110. } \\
\text { Medium }\end{array}$ & + ive & + ive \\
\hline
\end{tabular}




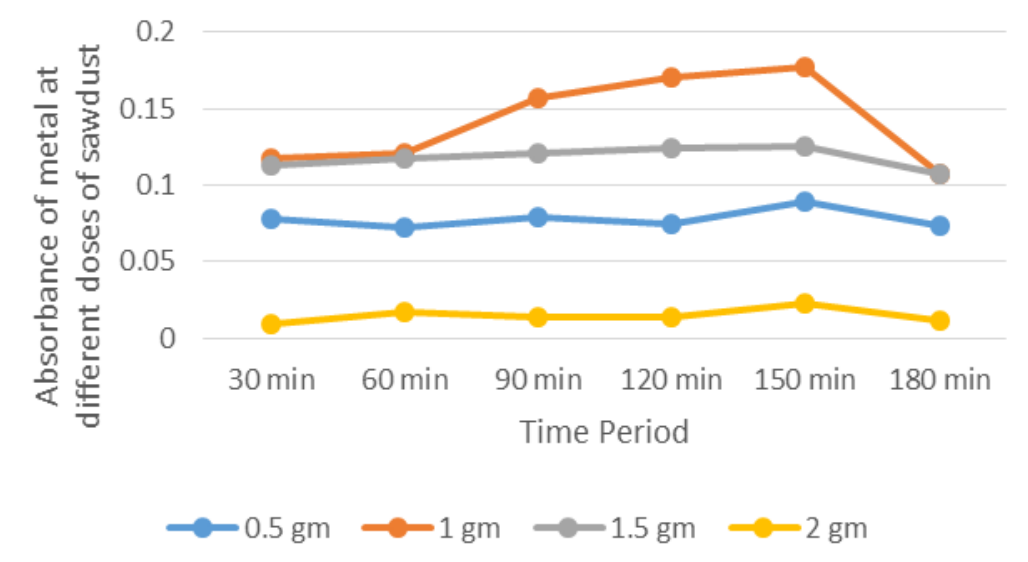

Figure 2. Effect of contact time on percentage absorbance of $\mathrm{Cr}$ (VI) at different doses of Sawdust (Wood dust)

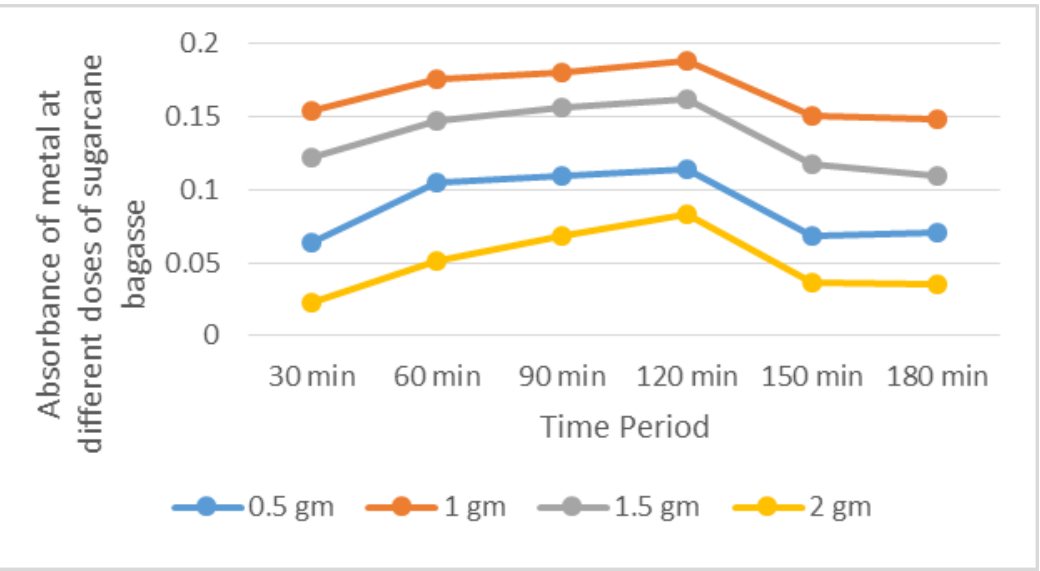

Figure 3. Effect of contact time on percentage absorbance of $\mathrm{Cr}$ (VI) at different doses of Saccharum officinarum (Sugarcane Bagasse)

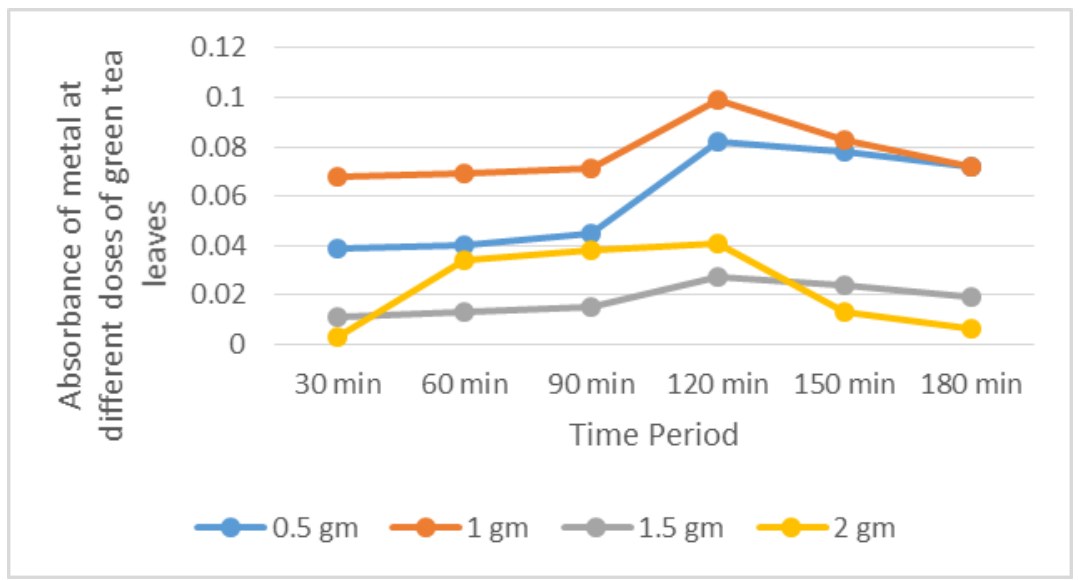

Figure 4. Effect of contact time on percentage absorbance of $\mathrm{Cr}$ (VI) at different doses of Camellia sinensis (Green Tea Leaves) 


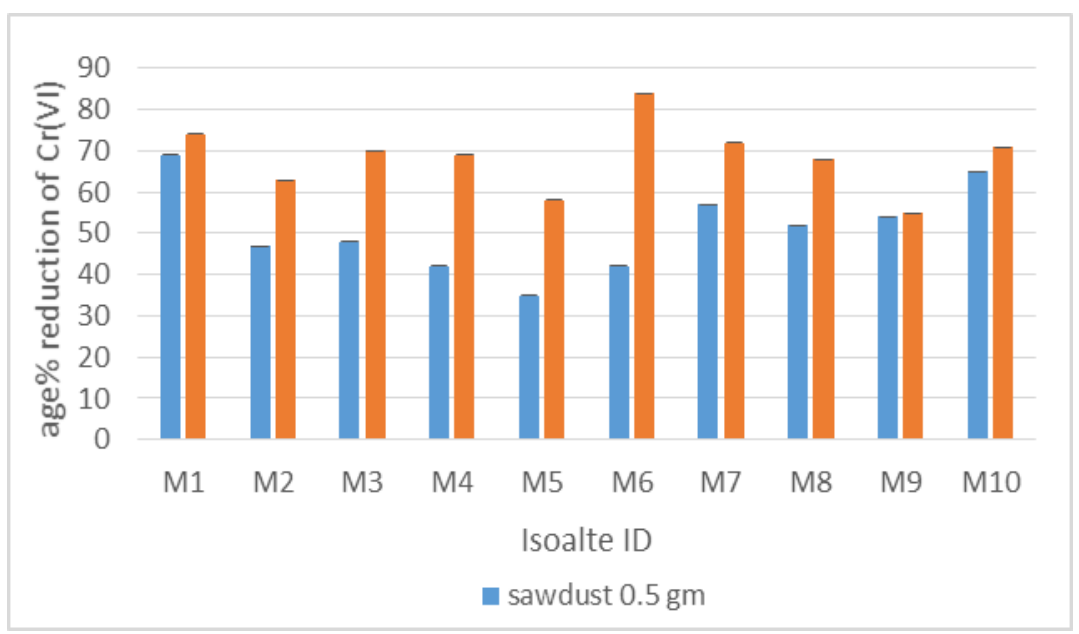

Figure 5. Combined effect of chromium resistant isolates and sawdust on the \%age removal of chromium

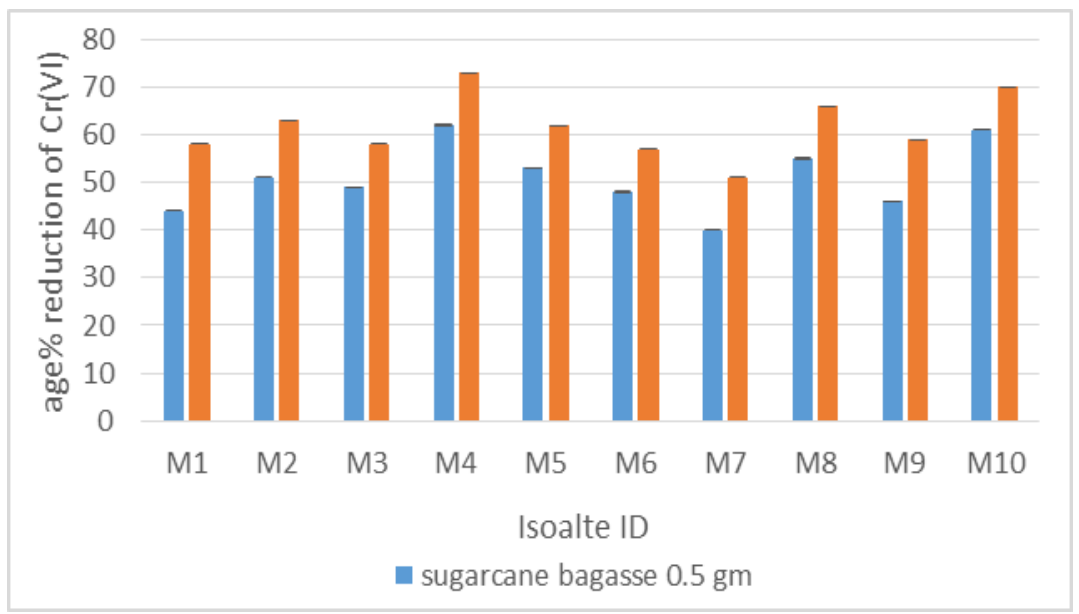

Figure 6. Combined effect of chromium resistant isolates and Green tea leaves (Camellia sinensis) on the \%age removal of chromium

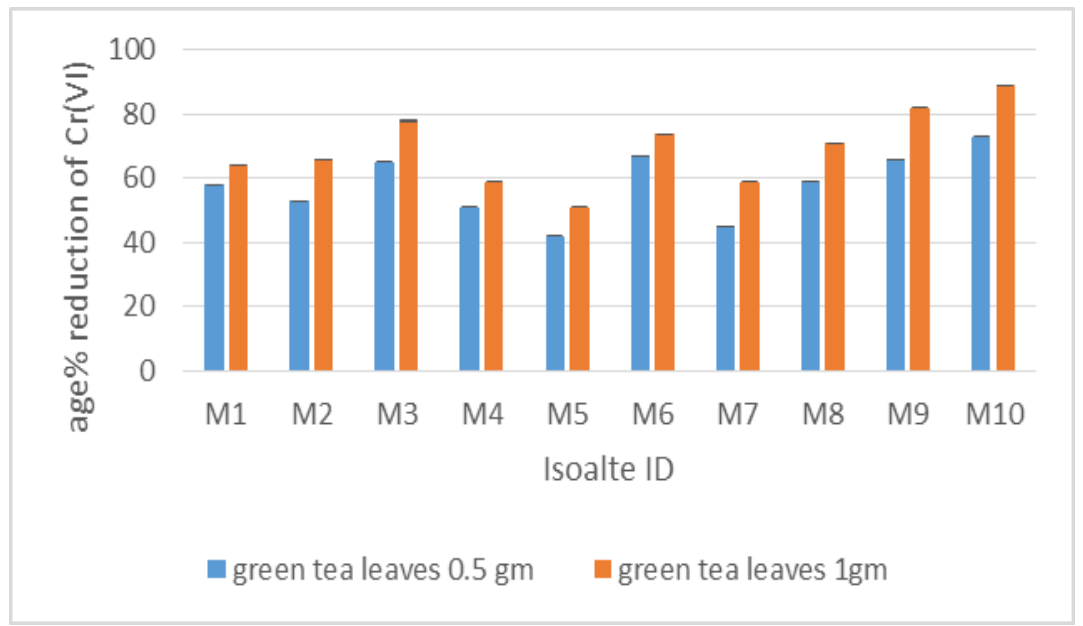

Figure 7. Combined effect of chromium resistant isolates and Sugarcane bagasse (Saccharumofficinarum) on the \%age removal of chromium 


\section{Discussion}

Rapid industrialization yields massive release of wastewater loaded with substantial biological complexes that are intolerable for the atmosphere and human fitness. Latest progressive green technical methods are being told to overawe the conservative methods of waste water treatment. Bacterium is the notable pathogen prevalent in waste water, source of various diseases and disorders with danger (Source: EPA's Report on the Environment, 2008). Bacteria dominant in different industrial discharges comprise Thiobacillus, Acinetobacter, Achromobacter, Nitrosomonasr, Nitrobacter, Achromobacter, Alcaligenes, Bacillus, Flavobacterium, Micrococcus, Staphylococcus and Pseudomonas [18].

Industries (electroplating, wood, textile, electronics, automobile etc.) holds chromium and salt ions in their waste water have toxic effects on the microbial associations of wastewater treatment systems [19]. Unregulated disposal of metals from industries (comprising effluents) into the surroundings destruct the biome [20] and influence the entire environment (21). Reduction of Cr (VI) to $\mathrm{Cr}$ (III) is therefore a potentially useful process for remediation of $\mathrm{Cr}$ (VI)-affected environments [22]. Bio-reduction of toxic $\mathrm{Cr}$ (VI) has practical importance because biological strategies provide green technology method that is cost-effective [23]. Present study utilized different adsorbents that reduce $\mathrm{Cr}$ (VI) to $\mathrm{Cr}$ (III).

Adsorbents (Sugar bagasse, green tea waste, saw dust and other organic wastes) were used to study the adsorption of $\mathrm{Cr}$ (VI) from wastewater, based on the experimental studies ( $\mathrm{pH}$ value, adsorption time, temperature and dose). Under the optimum conditions, the removal rate of chromium from wastewater using organic waste (sugar bagasse, green tea waste, saw dust, rice husk) can influence up to $91 \%$ [24]. Plasmids are extra chromosomal DNA, responsible for specific characteristics in organism. It supports bacteria to acquire tolerance and resistance mechanisms against heavy metals or other contaminated constituents in the toxic environment [25].

In present study, 30 bacterial isolates were isolated from water $(n=9)$ and soil samples $(n=9)$ collected from different industries. Among 30 isolates, only 10 isolates were screened positive for chromium reduction. Recent study determined that Staphylococcus spp. ( $S$. aureus and $S$. epidermidis) were present in the soil and waste water of industries and resistant to chromium metal. Adsorbents (saw dust, green tea leaves and sugarcane bagasse) were used in present study in different doses and time period to reduce the $\mathrm{Cr}$ (VI) from the waste water. Results showed that adsorbents with low doses $(0.5 \mathrm{~g}$ and $1 \mathrm{~g})$ with $\mathrm{pH}(2)$ and incubation time (120150 minutes) was effective $(89.4 \%)$ to remove higher concentrations of chromium metal, while isolate M1 and M4 were isolated from water samples and M10 was from soil sample showed maximum removal with the adsorbent dose of $1 \mathrm{~g}$ (Saw dust, Sugarcane bagasse and Green tea leaves).

\section{Conclusion}

Current study indicated that the Organic adsorbents (saw dust, green tea leaves and sugarcane bagasse) can be used to eliminate the hexavalent chromium from different industrial sources and considered as cheapest method for removal of heavy metals. Results of saw dust were greatest at the dose of $1 \mathrm{~g}(89.4 \%)$, while M1, M4 and M10 isolates showed maximum removal with the adsorbent dose of $1 \mathrm{~g}$ (Saw dust, Sugarcane bagasse and Green tea leaves). The current data is consistent with limited number of samples and bacterial isolates, more study and research is required to reveal the patterns.

\section{Authors' contributions}

Conceived the idea and designed experiments: M Muzaffar \& S Mazhar, Performed the experiments: M Muzaffar, Help in analyzing the data: SM Gohar, Discussed the results with her supervisors 
and all combinely contributed to the final manuscript: M Muzaffar.

\section{References}

1. Yang G, Chaofeng S \& Ju M (2014). Heavy Metal Contamination Assessment and Partition for Industrial and Mining Gathering Areas. Int J Environ Res Pub Health 11(7): 7286-730.

2. Demirbas A (2008). Heavy metal adsorption onto agro-based waste materials: A review. J Hazard Mater 157: 220-229.

3. Hua M, Zhang S, Pan B, Zhang W, Lv L \& Zhang Q (2012). Heavy metal removal from water/wastewater by nano-sized metal oxides: A review. $J$ Hazard Mater 211: 317-331.

4. Chandra Pandey PK \& Srivastava A (2004). Comparative toxicological evaluation of untreated and treated tannery effluent with Nostoc Muscorum L. (Algal assay) and microtox bioassay. J Environ Monit Asses 95:287-294.

5. Chingombe $P$, Saha $B$ \& Wakeman $R$ (2005). Surface modification and characterization of a coal-based activated carbon. $J$ Carbon 43(15):3132-3143.

6. Baruthio F (1992). Toxic effects of chromium and its compounds. J Biol Trace Elem Res 32: 145-153.

7. Stearns DM (2007). Chapter 3Multiple hypotheses for chromium (III) biochemistry: why the essentiality of chromium (III) is still question. In: Vincent, J.B. (Ed.), The Nutritional Biochem of Chromium (III) Elsevier 57-70.

8. Oladoja NA, Ololade IA, Alimi OA, Akinnifesi TA \& Olaremu GA (2013). Iron incorporated rice husk silica as a sorbent for hexavalent chromium attenuation in aqueous system. $J$ Chem Eng Res Des 91: 2691-2702.

9. Gricic I, Vujevic D, Sepcic J \& Koprivanac N (2009). Minimization of organic content in simulated industrial wastewater by Fenton type processes: a case study. J Hazard Mater 170: 954-961.

10. Mindlin S, Kholodii G, Gorlenko Z, Minakhina S, Minakhin L, Kalyaeva E, Kopteva A, Petrova M, Yurieva O \& Nikiforov V (2001). Mercury resistance transposons of Gramnegative environmental bacteria and their classification. J Res Microbiol 152(9): 811-822.

11. Silva L d, AA, Carvalho M A R d, Souza S AL d, Dias P M T, Filho R G d S, Saramago C S d M, Bento_C A d M. \& Hofer E (2012). Heavy metal tolerance $(\mathrm{Cr}, \mathrm{Ag}$ and $\mathrm{Hg}$ ) in bacteria isolated from sewage. Braz. J Microbiol 43(4): 1620-1631.

12. Yamina B, Tahar B \& Laure F M (2012). Isolation and screening of heavy metal resistant bacteria from wastewater: a study of heavy metal co-resistance and antibiotics resistance. J Water Sci \& Technol 66: 10.

13. Nasim K A, Shaliza I \& Piarapakaran S (2004). Review Paper: Elimination of Heavy Metals from Wastewater Using Agricultural Wastes as Adsorbents. Malaysian J Sci 2: 43-51.

14. Rane NM, Sapkal RS, Patil MB \& Shewale SP (2010). Use of naturally available low cost adsorbents for removal of $\mathrm{Cr}$ (VI) from waste water. Int. J chem sci and appl 1(2): 65-69.

15. Babel \& Kurniawan TA (2003). Lowcost adsorbents for heavy metals uptake from contaminated water: a review. J Hazard Mater 97(1): 219243.

16. Serrano G V (1998). Adsorption of mercury, cadmium and lead from aqueous solution on heat-treated and sulphurized activated carbon. $J$ Water Res 32(1):1-4.

17. Bergey's Manual. Understanding bacteria by Sheela Srivastava, Springer 2003, pp 40.

18. Amna A \& Fozia N (2012). Frequency Distribution of Bacteria Isolated from Different Industrial Effluents, 
Daffodil International University. $J$ Sci and Technol 7(1).

19. Stasinakis AS, Thomaidis NS, Mamais D, Papanikolaou EC, Tsakon A \& Lekkas TD (2003). Effects of chromium (VI) addition on the activated sludge process. $J$ Water Res 37: 2140-2148.

20. Narayani M \& Shetty K V (2013). Chromium Resistant Bacteria and Their Environmental Condition for Hexavalent Chromium Removal: A Review, J Environ Sci and Technol 43(9): 955-1009.

21. Chandra Pandey PK \& Srivastava A (2004). Comparative toxicological evaluation of untreated and treated tannery effluent with Nostoc Muscorum L. (Algal assay) and microtox bioassay. J Environ Monit Assess 95: 287-294.

22. Michel $C$, Brugna $M$, Aubert $C$, Bernadac A \& Bruschi M (2001).
Enzymatic reduction of chromate: comparative studies using sulfate reducing bacteria. J Appl Microbiol Biotechnol 55: 95-100.

23. Ganguli A \& Tripathi AK (2002). Bioremediation of toxic chromium from electroplating effluent by chromate reducing Pseudomonas aeruginosa $\mathrm{A} 2 \mathrm{Chr}$ in two bioreactors. J Appl Microbiol Biotechnol 58: 416420.

24. Satarupa D, Baishali P \& Paul AK (2014). Reduction of Hexavalent Chromium by Viable Cells of Chromium Resistant Bacteria Isolated from Chromite Mining Environment. J Min 8.

25. Erum H \& Aiyaz HS (2016). Heavy metal resistance and antibiotic resistance in hospital isolates of staphylococcus aureus from Karachi. Fuuast J Boils 6(1): 11-16. 